\title{
ASSESSMENT OF THE PROGRESS OF INTEGRATED PEST MANAGEMENT PRODUCTS IMPLEMENTATION INTO AGRICULTURAL PRODUCTION SPACE
}

\author{
OCENA POSTĘPU WDRAŻANIA INTEGROWANEJ OCHRONY ROŚLIN \\ W PRODUKCYJNEJ PRZESTRZENI ROLNICZEJ
}

\author{
Department of Chemistry, Microbiology and Environmental Biotechnology, West Pomeranian \\ University of Technology, Szczecin, Poland
}

\begin{abstract}
Streszczenie. Celem pracy była ocena postępów w zakresie wdrażania zasad integrowanej ochrony roślin (ang. Integrated Pest Management, IPM) w gospodarstwach rolnych. Zebrano opinie rolników na temat wdrażania integrowanej ochrony roślin w ich gospodarstwach oraz oceniono dostępność asortymentu biopreparatów jako rozwiązania alternatywnego dla ochrony chemicznej. Prawie $60 \%$ rolników, prowadzących gospodarstwa w systemie konwencjonalnym, deklarowało stosowanie chemicznych środków ochrony roślin profilaktycznie na wypadek wystąpienia agrofagów (co jest niezgodne z zasadami integrowanej ochrony roślin). Rolnicy poddani ankietyzacji w większości nie słyszeli o integrowanej ochronie roślin. Jednak możliwe jest to, że rolnicy znają ograniczenia wprowadzone w 2014 roku, jednak ich nie akceptują. Zaobserwowano, że w grupie rolników deklarujących znajomość zasad IPM wzrasta odsetek respondentów świadomych ekotoksyczności pestycydów. Dlatego informowanie rolników o potrzebie ograniczania chemizacji rolnictwa wydaje się uzasadnione. Rolnicy zwracają uwagę na niewielki asortyment biologicznych środków ochrony roślin oraz na potrzebę wsparcia finansowego tych rolników, którzy rezygnują z intensywnego stosowania chemicznych środków ochrony roślin.
\end{abstract}

Key words: integrated pest management, agriculture, pesticides, environment.

Słowa kluczowe: integrowana ochrona roślin, rolnictwo, pestycydy, środowisko.

\section{INTRODUCTION}

The introduction of obligations to apply the integrated pest management principles by all professional pesticide users results from the provisions of Art 14 of Directive 2009/128 /EC and Art. 55 of Regulation No. 1107/2009/EC. Understanding the bases of integrated pest management is possible, because they are published in Annex III to the above Directive and many guides and publications on the subject have been issued (Brodzińska 2009; Directive 2009/128 / EC of 21 October 2009). The negative effects of pesticides on the broadly understood public health is a documented fact (de Cock et al. 1994; Forma et al. 2013). For over a decade, the range of plant protection products is systematically reduced (in the first years after the Polish accession to the $\mathrm{EU}$, about $60 \%$ of active substances being under the

Corresponding author - Autor do korespondencji: Kinga Zatoń, Department of Chemistry, Microbiology and Environmental Biotechnology, West Pomeranian University of Technology, Szczecin, Juliusza Słowackiego 17, 71 - 434 Szczecin, Poland, e-mail: Kinga.Zaton@zut.edu.pl 
cataloguing, were withdrawn, and currently, the European Commission is planning to withdraw 75 active substances out of the market) (Commission Implementing Regulation (EU) 2015/408 of 11 March 2015; Matyjaszczyk 2007).

The reason for the withdrawal of pesticides from the market are conscious decisions of manufacturers giving up the procedure for the renewal of means because of the costs, as well as the detected negative effects of these substances on the environment and human health (Commission Implementing Regulation (EU) 2015/408 of 11 March 2015; Wasim et al. 2009). An intensive use of chemicals in agriculture has led to the disturbance in the natural balance in terrestrial and aquatic ecosystems. A very large group of pesticides are toxic to aquatic organisms (toxicity data are issued in the SDS of a given pesticide) and still commonly used in the ecosystems with watercourses and reservoirs (Sopińska et al. 2000; Cavas and Konen 2007). For instance, it took several decades, the use of herbicides containing atrazine and simazine (used mainly for maize), before they were withdrawn from trading. It is now wellknown that these substances affect the reduction in the number of males in amphibian populations (and not only) and they are the cause of de-masculinization of many aquatic organisms' males (Hayes et al. 2003, 2011). On the other hand, the use of plant protection means makes farmers are able to quickly and effectively inhibit the development of pathogens and weeds (Badowski 2004; Lisek 2010). The ease and predictability of the chemical action effects facilitates the work of farmers and generates immediate profits. It also causes that a farmer does not need to know the ecological relationships between organisms in agrocenosis, or wasting time for insightful observations of the cereals crop state; in case of pest attack, he use the sprays (Sikorska and Wędzisz 2009; de Morais et al. 2016). Unfortunately, in the pursuit of greater profit and the facilitation in plant production (animal too it applies to antibiotics and hormones), these specifics began to be used prophylactically, i.e. just in case That practice contributed to the chemization of our environment, starting from the contamination of soil and water, and ending on animals and human (Gnusowski et al. 2011).

An integrated system of plant protection allows the use of pesticides only if there is no alternative, but does not allow the use of any chemicals, "just in case", and certainly for other purposes, e.g. to desiccate the cereals (Kucharski et al. 2012). Prophylactic applications of pesticides and antibiotics on a massive scale falls within the scope of humanity self-destructive activities. Scientific studies published in reputable journals clearly show a progressive positive correlation of the chemicals use in the environment with increased levels of civilization diseases (Hołownicki et al. 2011; Martini et al. 2012). The problem is global and results from the fact of a conflict between the ad hoc financial profits of corporations and farmers, vs. the public health (Kowalska et al. 2012). Systematically growing concern about public health has contributed to the increase in the promotion of alternative agricultural systems, the grounds of which were supposed to limit the use of artificial fertilizers and chemical pesticides (Kałuża 2009). Opinion of the European Commission in connection with the intensification of environmental pollution due to chemical plant protection products resulted in the introduction of a sustainable system of plant protection against pathogens and weeds, which is in force within the whole European Union (Dubas 2007). This means that farmers are obliged to fight against pathogens and weeds primarily using mechanical and biological means, while taking into account the natural ecological relationships between agro-biocenosis organisms to eliminate disease-invoking pathogens. In this case, the use of pesticides is 
justified only when all other methods fail. The guidelines contained in the legislation established by the European Commission (Dubas 2007), do not allow cereal desiccation before harvest and the chemical seed dressing in the agricultural. These activities are not part of eliminating the real threats of pests and weeds, and only facilitate the farmer's work. Of course, integrated pest management not only focuses on the issue of the pesticide residues reduction in agricultural crops, instead it is a set of many tips and rules for farmers cultivating different plant species. The implementation of such firm action to limit the spread of crop protection chemicals within the environment has to promote not only the reduced presence of pesticides in the fields, but also in agricultural crops, and consequently, in foods such as bread, fruits and vegetables as well as processed products, which greatly affects the human organism. Customs example of this state of affairs is A controversial issue of commonly used glyphosate-containing herbicides (e.g. Roundup) by farmers is an apt example of this state of affairs (Official Gazette of the Minister of Agriculture and Rural Development).

Many scientists concordantly confirmed the impact of glyphosate on functions of genetic material in the cells of many organs and endocrine system of both animals and humans (Hołownicki et al. 2011; Martini et al. 2012). According to Gasnier et al. [2009], who studied the influence of agents with glyphosate on human hepatic cells of HepG2 line, these herbicides had much stronger effects of cell viability in contrast to the glyphosate itself. In addition, they reported on DNA damage of test cells during their incubation in 5ppm (Grand Truvax) and the inhibitory effect of glyphosate on activity of the key aromatase enzyme at a concentration of $10 \mathrm{ppm}$, which resulted in impairment of normal endocrine hepatic activity. In turn, Richard et al. (2005), who studied the reaction of human placenta cells towards Roundup and glyphosate, confirmed the toxicity of the pesticide on a cell viability. As has been shown in studies, only a 1-hour exposure of placenta cells to Roundup reduced their count by $70 \%$. The study has also confirmed the decrease in the amount of the aromatase enzyme in cells by $50 \%$ even at a concentration of $0.04 \%$ Roundup in cell culture. Similarly, other researchers have received in their studies, results pointing to the negative impact of pesticides on animals. According to Sopińska et al. (2000), Roundup at a concentration of just $4 \mathrm{mg} / \mathrm{l}$ leads to the decline in a performance of carp immune system. The author has also confirmed that, as in the case of people, studied pesticide causes damage to the hepatic cells, which ultimately was observed during the post-mortem histopathology of tested fish. Researchers around the world have noted similar findings. It is proved by considerations of Clair's et al. (2012), who examining the impact of Roundup Bioforce on the testes cells at rat, announced about the damage to the Leydig cells and thus a decrease in testosterone levels by $30 \%$ at their exposure to the aforementioned pesticide at a concentration of only $1 \mathrm{ppm}$. In turn, the testicular and adrenal hyperplasia along with the testosterone reduction by about $30 \%$, have been found in study performed by Romano et al. (2010). The researchers eventually attempted to investigate the effects of Roundup Transorob, like the team of Sopińska, on rats. Results of both teams provide irrefutable evidence that pesticides containing glyphosate have adverse or even lethal effect to the endocrine system and many organs, both in humans and animals, which gives a lot of food for thought.

Reports of the research team led by Shehata (2013) should not be ignored. Scientists undertook the assessment of the impact of glyphosate on microorganisms, that are potential pathogens and symbionts to people. Their results showed that even high doses of glyphosate did not significantly affect the growth of bacteria being a potential threat to health, but in relation to the symbiotic microorganisms, depending on the species, they caused moderate through 
very high sensitivity. This allows to perfectly illustrate how much chemical pesticides impair the proper functioning of living organisms. However, the alarming reports of the scientific community have so far not led to the resumption of verification research upon the harmful effects of glyphosate-containing herbicides and glyphosate itself. They are developed and implemented financial instruments of the European Union to encourage farmers to adopt organic farming practices (Kiełbasa and Krysztoforski 2009; Bempah et al. 2012).

The positive effect of their implementation in EU countries were to be the environmental values, which were obtained through the dissemination of good agricultural practice, maintaining the natural habitats, and above all, reducing the use of pesticides and fertilizers (Brodzińska 2009). Although there is no single model pattern of the Agricultural-Environmental Program in the EU, all these involve the only requirement that was specified in the Regulation of the Council of the EU 1257/99 on technical and economic measurability of farmer's work effects (Nowacka et al. 2013). A great advantage, that contributed to the positive response of farmers, was the subsiding of the farmers' participation in these programs from the EU budget (Bempah et al. 2012). Unfortunately, the subsidizing of organic farming, despite of the willing adjustment of conventional farms in this direction, does not ensure the maintenance of such a change for a longer period. Examples for this are Finland and Austria, which in 2006 were characterized by a very high proportion of organic farms, while in subsequent years, these values were lower (Kazimierczak et al. 2010; de Morais et al. 2016). Unfortunately, the subsidizing of ecological farming, although willing adjustment in the direction of conventional farms, does not ensure the maintenance of such a change for a longer period. The perfect example are Finland and Austria, which in 2006 were characterized by a very high proportion of farms with organic farming (Keikotlhaile et al. 2010).

Another issue is related to the availability of biological pesticides. It often appears that farmers simply do not have any access to biological preparations. Chemical rather than biological ones are definitely more readily available to them. The most important thing is to convince farmers about the legitimacy of change. Will immediate economic gains win with public health (implementation of IOR)? Currently, there is no understanding among farmers to the concept of limiting the use of chemicals in the environment. The confirmation of this thesis are farmers' statements in media and on internet forums about integrated pest management and pesticide withdrawal from trade (Council Regulation (EC) No. 1257/1999 of 17 May 1999; Hayes et al. 2003; Matyjaszczyk 2007; Romano et al. 2010; Hayes et al. 2011; Jardim and Caldas 2012). A growing demand for food produced in organic farms is an opportunity, but this is still a small percentage of the total agricultural production.

\section{MATERIAL AND METHODS}

The surveys were used to collect information from respondents - farmers. Surveys were conducted among farmers running conventional and ecological farming on small or large area (Tables 1,2). Several hundred questionnaires were sent or personally delivered to farmers in urban areas of Świdwin, Koszalin and Szczecin in Western Pomerania (Poland). The choice of the study area was due to the fact of the agricultural nature of economic activity within this area. Arable land constituted $48.7 \%$ of the total province area (Brodzińska 2009; Directive 2009/128 / EC of 21 October 2009; Forma et al. 2013). In return, 95 completely filled questionnaires were obtained. 
Table 1. Summary of farmers' responses relating to the characteristics of farms (multiple choice of respondents) Tabela 1. Charakterystyka gospodarstw (możliwość wielokrotnego wyboru odpowiedzi)

\begin{tabular}{|c|c|c|c|c|c|}
\hline \multirow[t]{2}{*}{$\begin{array}{l}\text { The type of farm } \\
\text { Rodzaj gospodarstw }\end{array}$} & \multirow{2}{*}{$\begin{array}{l}\text { The total number } \\
\text { of farms from all } \\
\text { respondents } \\
\text { Liczba gospodarstw } \\
{[\%]}\end{array}$} & \multicolumn{4}{|c|}{$\begin{array}{l}\text { The type of production relating to the way } \\
\text { of farms' size and cultivation system } \\
\text { Rodzaj produkcji ze względu na rodzaj uprawy } \\
\text { i wielkość gospodarstwa [\%] }\end{array}$} \\
\hline & & $\begin{array}{l}\text { crops } \\
\text { zboża }\end{array}$ & $\begin{array}{c}\text { vegetables } \\
\text { warzywa }\end{array}$ & $\begin{array}{l}\text { fruits } \\
\text { owoce }\end{array}$ & $\begin{array}{l}\text { other } \\
\text { inne }\end{array}$ \\
\hline $\begin{array}{l}\text { Large - scale farms cultivated in } \\
\text { organic system } \\
\text { Duże gospodarstwa ekologiczne }\end{array}$ & 1 & - & 100 & 100 & 100 \\
\hline $\begin{array}{l}\text { Small - scale farms cultivated in } \\
\text { organic system } \\
\text { Małe gospodarstwa ekologiczne }\end{array}$ & 11 & 4 & 50 & 40 & 6 \\
\hline $\begin{array}{l}\text { Large - scale farms cultivated in } \\
\text { conventional system } \\
\text { Duże gospodarstwa } \\
\text { konwencjonalne }\end{array}$ & 9 & 92 & - & - & 8 \\
\hline $\begin{array}{l}\text { Small - scale farms cultivated in } \\
\text { conventional system } \\
\text { Małe gospodarstwa } \\
\text { konwencjonalne }\end{array}$ & 74 & 70 & 12 & 11 & 7 \\
\hline
\end{tabular}

Questionnaires included alternative and disjunctive, as well as open and closed questions. The questionnaire was divided into three thematic fields. The first concerned the current situation in the farm in terms of the use of pesticides and biological preparations, divided into large and small-area farms. The second range of questions concerned the awareness of farmers about changes in legislation and the introduction of an integrated system of plant protection, as well as dangers of pesticides. The design of the questionnaire also allowed to survey the farmer's priorities (profit resulting from the rate and efficiency of pesticides vs. concern about the quality of crops) and their attitude to give up the chemical plant protection. Other type of study was the community interview, in which respondent anonymously answered the prepared questions by a telephone call. The study was conducted on 20 respondents, employees of randomly selected points of distribution and sale of chemical and biological plant protection means in Western Pomerania. Closed and open questions concerned: range of biological means available in the store/warehouse, possibility of the order of biological agents for use on large crop areas, example of the costs for such protection.

\section{RESULTS}

Characteristics of surveyed farms in terms of the pesticide use. Surveys were obtained from 10 large-scale and 85 small-scale farms, were produce are crops, vegetables, fruits and other plants (Table 1, Fig. 1). Most farmers still intensive use the chemical plant protection as the primary way to combat plant weeds and pests on farms conducted in the conventional system ( $87 \%$ of all surveyed farms, including 9 large-scale and 74 small-scale). 
Table 2. Summary of questions and farmers' responses relating to the way of plant protection, integrated system of plant protection (multiple choice of respondents)

Tabela 2. Opinie rolników na temat sposobu ochrony roślin, integrowanego systemu ochrony roślin (możliwość wielokrotnego wyboru odpowiedzi)

\begin{tabular}{|c|c|c|c|}
\hline $\begin{array}{l}\text { Questions and possible } \\
\text { responses } \\
\text { Zagadnienia i możliwe } \\
\text { odpowiedzi }\end{array}$ & $\begin{array}{l}\text { The total number of } \\
\text { farms from all } \\
\text { respondents } \\
\text { Liczba gospodarstw [\%] }\end{array}$ & $\begin{array}{l}\text { Concerns only farms } \\
\text { cultivated in the organic } \\
\text { system } \\
\text { Tylko gospodarstwa } \\
\text { ekologiczne [\%] }\end{array}$ & $\begin{array}{c}\text { Concerns only farms } \\
\text { cultivated in the conventional } \\
\text { system } \\
\text { Tylko gospodarstwa } \\
\text { konwencjonalne [\%] }\end{array}$ \\
\hline \multicolumn{4}{|c|}{$\begin{array}{l}\text { The use of plant protection products } \\
\text { Wykorzystanie chemicznych środków ochrony roślin }\end{array}$} \\
\hline $\begin{array}{l}\text { Only when necessary - } \\
\text { emergency protection } \\
\text { Tylko, gdy jest realna } \\
\text { potrzeba }\end{array}$ & 17 & - & 20 \\
\hline $\begin{array}{l}\text { Only preventive - just in case } \\
\text { Tylko profilaktycznie }\end{array}$ & 3 & - & 4 \\
\hline $\begin{array}{l}\text { Multiple, preventive and } \\
\text { emergency use } \\
\text { Kompleksowo, czyli na } \\
\text { wszelki wypadek i gdy } \\
\text { jest realna potrzeba }\end{array}$ & 46 & - & 54 \\
\hline $\begin{array}{l}\text { Not using } \\
\text { Bez stosowania }\end{array}$ & 13 & 100 & - \\
\hline \multicolumn{4}{|c|}{$\begin{array}{l}\text { The use of natural treatments to support the protection and growth of plants, such as crop rotation, } \\
\text { fertilization, natural and organic biopesticides, etc. } \\
\text { Wykorzystanie naturalnych zabiegów wspomagających ochronę i rozwój roślin, takich jak płodozmian, } \\
\text { nawozy naturalne, biopestycydy }\end{array}$} \\
\hline $\begin{array}{l}\text { I use those treatments } \\
\text { Wykorzystuję }\end{array}$ & 23 & 100 & 12 \\
\hline $\begin{array}{l}\text { I don't use those } \\
\text { treatments } \\
\text { Nie wykorzystuję }\end{array}$ & 87 & - & 88 \\
\hline $\begin{array}{l}\text { I don't know } \\
\text { Nie wiem }\end{array}$ & - & - & - \\
\hline \multicolumn{4}{|c|}{$\begin{array}{l}\text { Are you aware of principles of integrated pest protection system? } \\
\text { Czy zna Pani / Pan zasady integrowanej ochrony roślin? }\end{array}$} \\
\hline $\begin{array}{l}\text { Yes } \\
\text { Tak }\end{array}$ & 31 & 100 & 17 \\
\hline $\begin{array}{l}\text { No } \\
\text { Nie }\end{array}$ & 69 & - & 83 \\
\hline \multicolumn{4}{|c|}{$\begin{array}{l}\text { Is in your opinion possible to achieve large crops without pesticides? } \\
\text { Czy według Pani / Pana opinii możliwe jest otrzymanie dużych plonów bez pestycydów? }\end{array}$} \\
\hline $\begin{array}{l}\text { Yes } \\
\text { Tak }\end{array}$ & 26 & 97 & 17 \\
\hline No & 63 & 3 & 70 \\
\hline $\begin{array}{l}\text { I don't know } \\
\text { Nie wiem }\end{array}$ & 11 & - & 13 \\
\hline
\end{tabular}

Would you pay more than today for protective product, if it would be effective and safe for health (without toxic chemicals)?

Czy zapłaciłby / zapłaciłaby Pan / Pani więcej niż obecnie za środek ochrony roślin, bezpieczny dla zdrowia (biologiczny, a nie chemiczny)?

\begin{tabular}{lccc} 
Yes, but not much more & 43 & 60 & 42 \\
Tak, ale nie dużo więcej & 1 & 3 & - \\
\hline $\begin{array}{l}\text { Yes, much more } \\
\text { Tak, nawet dużo więcej }\end{array}$ & 52 & 32 & 58 \\
\hline $\begin{array}{l}\text { No } \\
\text { Nie }\end{array}$ & 2 & 5 & - \\
\hline $\begin{array}{l}\text { I don't know } \\
\text { Nie wiem }\end{array}$ & 52 & 4
\end{tabular}

What form of pesticides and fertilizers is the best and eagerly bought?

Jaka forma użytkowa pestycydów i nawozów jest najlepsza i najczęściej kupowana?

\begin{tabular}{llcc}
\hline Liquid & 47 & 58 & 46 \\
Płynna & 47
\end{tabular}


Table 2. Summary of questions and farmers' responses relating to the way of plant protection, integrated system of plant protection (multiple choice of respondents) (cont.)

Tabela 2. Opinie rolników na temat sposobu ochrony roślin, integrowanego systemu ochrony roślin (możliwość wielokrotnego wyboru odpowiedzi) (cd.)

\begin{tabular}{|c|c|c|c|}
\hline $\begin{array}{l}\text { Questions and possible } \\
\text { responses } \\
\text { Zagadnienia i możliwe } \\
\text { odpowiedzi }\end{array}$ & $\begin{array}{l}\text { The total number of } \\
\text { farms from all } \\
\text { respondents } \\
\text { Liczba wszystkich } \\
\text { gospodarstw [\%] }\end{array}$ & $\begin{array}{l}\text { Concerns only farms } \\
\text { cultivated in the organic } \\
\text { system } \\
\text { Tylko gospodarstwa } \\
\text { ekologiczne [\%] }\end{array}$ & $\begin{array}{c}\text { Concerns only farms } \\
\text { cultivated in the conventional } \\
\text { system } \\
\text { Tylko gospodarstwa } \\
\text { konwencjonalne [\%] }\end{array}$ \\
\hline $\begin{array}{l}\text { Constant } \\
\text { Stała }\end{array}$ & 38 & 32 & 39 \\
\hline $\begin{array}{l}\text { Other } \\
\text { Inna }\end{array}$ & - & - & - \\
\hline $\begin{array}{l}\text { It doesn't matter } \\
\text { Nie ma znaczenia }\end{array}$ & 14 & 10 & 15 \\
\hline
\end{tabular}

Which problems associated with the use of pesticides are the most important for you?

Co jest dla Pana / Pani największym problemem w stosowaniu pestycydów?

Too high price in relation
to profits from the
cultivation
$\begin{aligned} & \text { Zbyt wysoka cena } \\ & \text { w odniesieniu do zysków } \\ & \text { z upraw }\end{aligned}$

Technical problems such

as water consumption

and hardware application

di soil or on the plant

Problemy natury

72

83

technicznej, np. zużycie

wody i sprzętu przy

stosowaniu do gleby lub

na roślinę

Contamination of crops

and soil with chemicals

Zanieczyszczenia gleby

$31 \quad 100$

17

i roślin chemikaliami

Frequent inefficiencies

and the short time of

action

76

92

i krótki czas działania

There's no problem

Nie ma problemu

Is it possible at your farm to dispense with pesticides or significant reduction of use, and the use of more expensive, but safe products?

Czy w Pana / Pani gospodarstwie jest możliwe zrezygnowanie lub zredukowanie użycia pestycydów i zastąpienie ich droższymi, ale bezpieczniejszymi produktami?

\begin{tabular}{|c|c|c|c|}
\hline $\begin{array}{l}\text { Yes, health of consumers } \\
\text { and family is the most } \\
\text { important } \\
\text { Tak, zdrowie } \\
\text { konsumentów i rodziny } \\
\text { jest najważniejsze }\end{array}$ & 41 & 100 & 32 \\
\hline $\begin{array}{l}\text { No } \\
\text { Nie }\end{array}$ & 58 & - & 67 \\
\hline $\begin{array}{l}\text { Not answered } \\
\text { Brak odpowiedzi }\end{array}$ & 1 & - & 1 \\
\hline
\end{tabular}




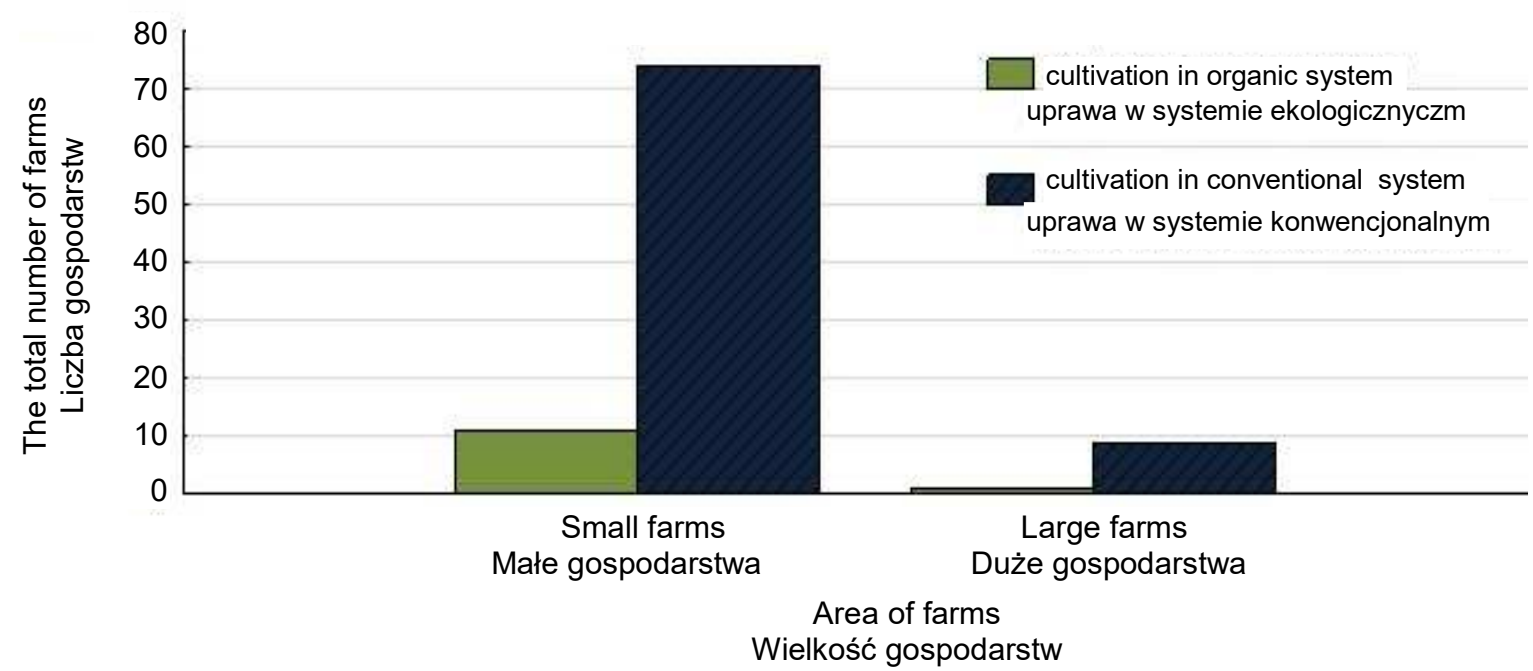

Fig. 1. Characteristics of surveyed farms in terms of acreage and cultivation system Ryc. 1. Charakterystyka gospodarstw pod względem wielkości i systemu uprawy

Organic farms accounted for the total of $13 \%$ of all surveyed objects ( 12 farms); farmers did not admit to use chemical protection means in these cases. The owners of organic farms are legally obliged to use a narrow, dedicated to organic farming, pool of plant protection products, mainly of natural origin. All owners of farms under survey, regardless of the farm size, have reported problems with fungal and bacterial phyto - pathogens in their fields. Besides the owners of organic farms, surveyed farmers also admitted that they apply pesticides to eliminate diseases and weeds (regardless of the size of their crop acreage). These elements supporting the plant development as the use of natural fertilizers, crop rotation, plant varieties resistant to pests and bio-pesticides; are used in all surveyed large-scale farms, but only at approximately $50 \%$ of respondents with small-scale farms. When considering the use of natural methods to promote plant growth among farmers having conventional farms ( $87 \%$ of all surveyed farms), it can be estimated that about $12 \%$ of them apply the natural ecological dependencies among agrocoenotic organisms (crop rotation, bio-preparations, natural fertilization) - Fig. 2, Table 2.

Analysis of survey results concerning the circumstances of the pesticide use by farmers took into account only the questionnaire obtained from farms conducted in the conventional system ( $87 \%$ of all farms). These respondents confirmed the use of pesticides to protect crops, but the essence of the problem related to the fact whether they use chemical plant protection means preventively just in case (not in accordance with the guidelines of Integrated Pest Management), or only temporarily, when other methods are inadequate. Fifty-eight per cent of the sample farmers declared the prophylactic use of chemical agents, before there is a problem with pathogens or weeds. Among this group, respondents who use pesticides very often, both prophylactically and casually (about $78 \%$ of conventional farms), or only prophylactically (4\%) can be divided. Farmers who use pesticides ad hoc, i.e. only when it is necessary and according to the principles of Integrated Pest Management, comprise 20\% of respondents having conventional farms. 


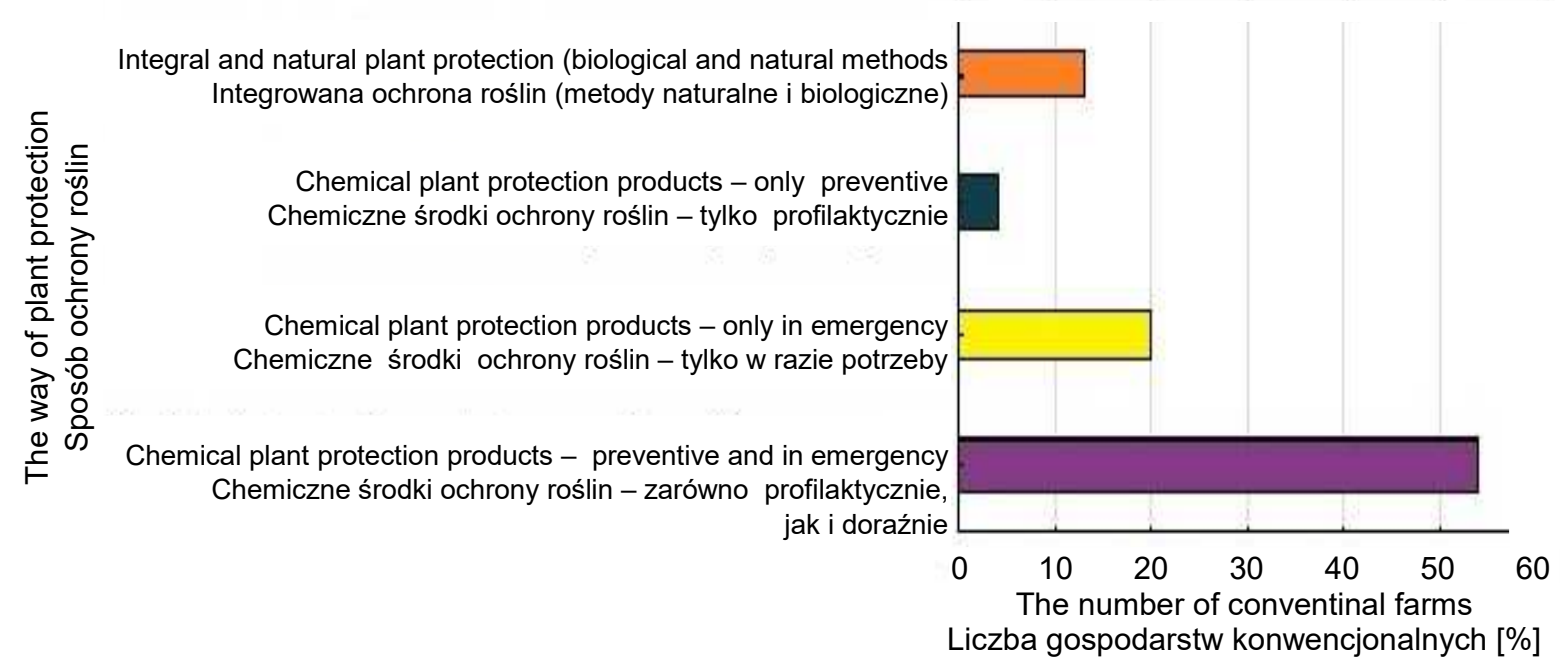

Fig. 2. Method for crops protection (multiple choice of respondents)

Ryc. 2. Stosowane sposoby ochrony roślin (możliwość wielokrotnego wyboru odpowiedzi)

Assessment of farmers' awareness about the introduction of Integrated Pest Management to agricultural space. Only $31 \%$ of all surveyed farmers at least heard of the Integrated Pest Management and the need to limit the use of pesticides. Among the owners of conventionally operated farms, they made only about $17 \%$. At the same time, these farmers declared the knowledge of Integrated Pest Management and continue to apply pesticides in an unauthorized manner, reflecting the lack of acceptance of the official restrictions introduction. Among all farmers (running organic and conventional farms) admitting to the knowledge of Integrated Pest Management system principles, nearly half of them indicates that the contamination of soil and agricultural goods with pesticides is a problem. Farmers usually indicated several key issues related to the use of pesticides. Half of the conventional farmers, who are familiar with the principles of Integrated Pest Management, admitted that the harmfulness of pesticides is a problem, in addition to the high prices for plant protection products and technical problems relating to their application (Fig. 3, Table 2).

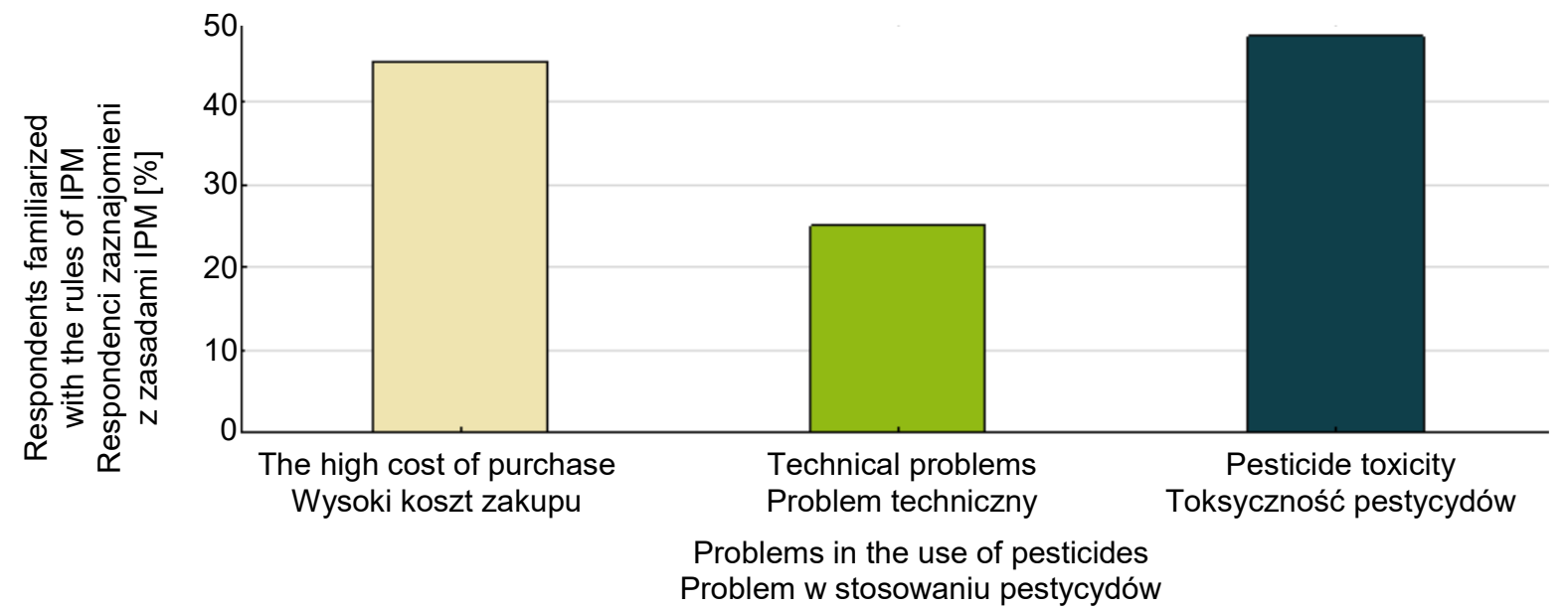

Fig. 3. Problems associated with the use of pesticides in the opinion of farmers who know the integrated pest management rules (multiple choice of respondents)

Ryc. 3. Problemy związane ze stosowaniem pestycydów według opinii rolników, którzy znają zasady integrowanego zarządzania szkodnikami (możliwość wielokrotnego wyboru odpowiedzi) 
Priorities for farmers and prospects of Integrated Pest Management. The Fig. 4 and the table 2 present data on farmers from conventional farms declaring the knowledge upon principles of Integrated Pest Management. While analyzing the results of polls from all conventional farms, it turns out that about $85 \%$ of farmers do not see any alternative to chemical plant protection, and it is a key element of agricultural technology for them. Considering the possible problems associated with the use of pesticides, only $17 \%$ of farmers from all conventional farms notes the problem of pesticide eco-toxicity (as much as declared the knowledge of Integrated Pest Management). The rest of respondents (83\% of conventional farms) point to economic and technical problems as a priority in the use of chemical protection in their fields. Among the owners of organic farms, the conviction that it is possible to obtain satisfactory yields without chemicals dominates ( $97 \%$ of this group of respondents) and the aspect of soil and food contamination during the use of chemical plant protection is more frequently mentioned.

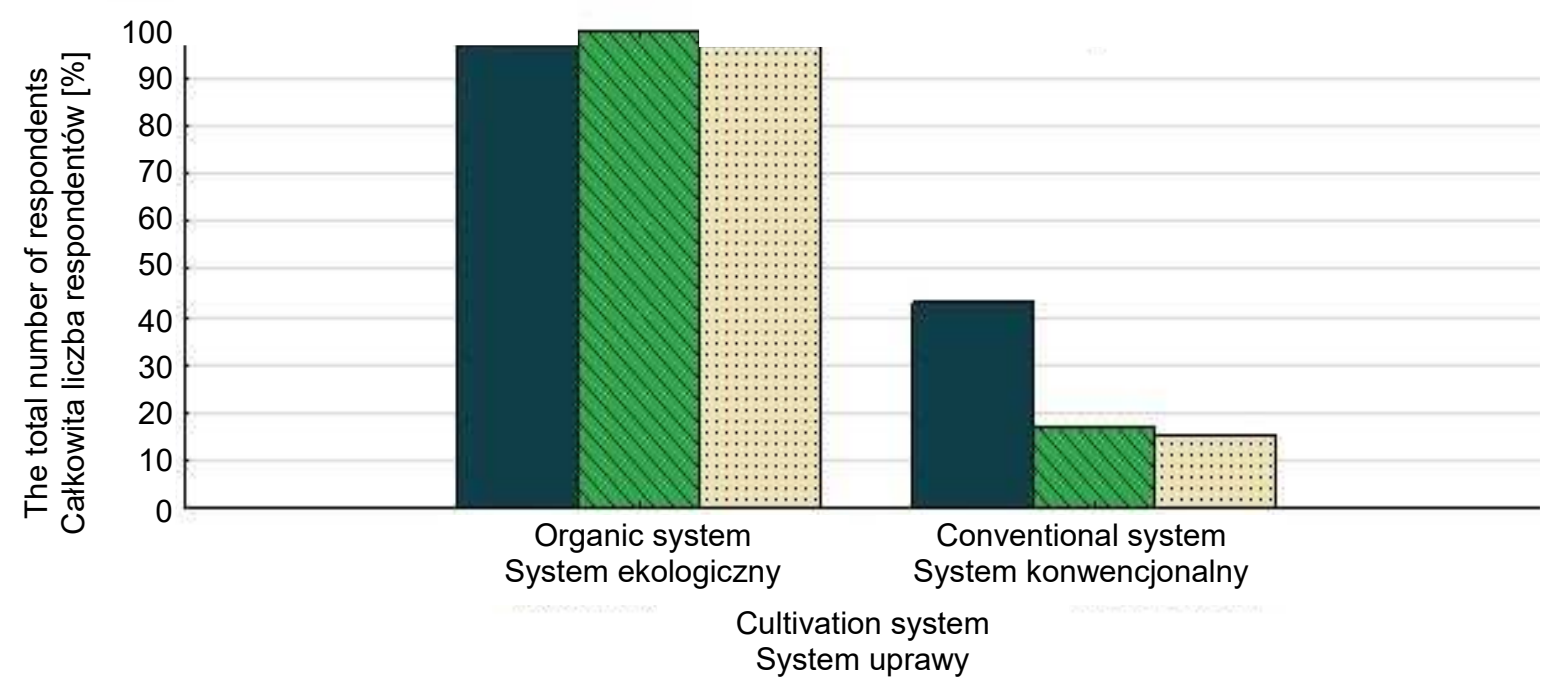

farmers expression of readiness to additional funding for effective protection of plants gotowość rolników do poniesienia większych kosztów na biologiczne środki ochrony roślin

predicting the toxicity of pesticides as the big gest problem with the use of chemicals in agriculture toksyczność pestycydów jako największy problem w stosowaniu chemicznej ochrony roślin w rolnictwie

…? granting the possibility of obtaining highlevel of Fields without prsticides

potwierdzenie możliwości uzyskania dużych plonów bez stosowania chemicznej ochrony roślin

Fig. 4. Attitude of farmers about Integrated Pest Management and environmental protection (multiple choice of respondents)

Ryc. 4. Opinie rolników nt. stosowania środków ochrony roślin i ochrony środowiska (możliwość wielokrotnego wyboru odpowiedzi)

Interesting results were obtained regarding the farmers' wish to buy an effective compact ecological mean, which would combine features of organic fertilizer and bio-pesticide, but more expensive as compared to the current range. Farmers from organic farms, in most cases, would be interested in such an agent, however, with only a slight increase in prices compared to the current prices. Also, about half of the conventional farmers would be interested in such a compact mean (42\%). About $13 \%$ of all respondents pointed to the health of consumers and their families as a priority when choosing a product from a range of plant protection means, regardless of price. 
Most of them were the owners of organic farms. In order to verify the availability of bio-pesticides, 20 random shops and garden centers were selected, of which only 7 actually had available preparations containing microorganisms or plant extracts and 5 allowed to get them after the order. Among biological plant protection means readily available in Poland, following may be mentioned: Biosept, Constant XX, Polywersum WP Target., Timorex Gold 24 EC, Biczos, Ems, and Dipel WG. Their widest range is available in large retails containing gardening divisions, e.g. Bricomarche, Leroy Merlin, and some smaller shops belonging to the gardening network having more branches. On the other hand, small garden shops, including florists, allow a little access to bio-pesticides.

Available bio-preparations can be usually purchased in a liquid form in packs of around 0.5 liter or as a powder weighing several to several tens of grams. Their prizes oscillate within 10-100 PLZ (2-20 EUR) per pack. Most small shops do not offer biological plant protection products, and their owners explain their little interest and sales. Definitely more means are available in Germany, while in Poland, dominate quantitatively bio-preparations generally supporting the growth of plants quantitatively dominate in Poland (large variety of mycorrhizal vaccines by Mycoflor), while there is no biological means to combat specific pests.

\section{DISCUSSION}

About $60 \%$ of farmers, who run conventional system, declare the prophylactic use of pesticides before the threat of weeds or pests (as is clear from our research). This action is inconsistent with the guidelines of Integrated Pest Management having been in force since 2014 and directed to all farmers (Council Regulation (EC) No 1257/1999 of 17 May 1999; Directive 2009/128 / EC of 21 October 2009; Commission Implementing Regulation (EU) $2015 / 408$ of 11 March 2015). Even in a group of farmers declaring knowledge of the principles of Integrated Pest Management (this is only $17 \%$ of farmers running the conventional farming system), prophylactic use of pesticides is the norm. When analyzing the survey results, it is clear that knowledge of Integrated Pest Management has not reached the majority of farmers.

The relevant legislation bodies governing the Polish agriculture, according to the guidelines of the Directive on the sustainable use of plant protection products (Directive 2009/128 / EC of 21 October 2009), are theoretically obliged and provide training of farmers upon the Integrated Pest Management issues (Hołownicki et al. 2011). This is confirmed in the report by Kiełbasa and Krysztoforski (2009). It was, however, noted in this paper that farmers not accepting the idea of limiting the consumption of chemical plant protection, either do not know about it or they know but prefer to declare ignorance. The priority for farmers is the high yield and profit, while social costs resulting from the spread of pesticides within the environment, in their opinion, are exaggerated or necessary to bear (Agricultural Forum about herbicides, Agricultural Forum „Awaken”). Only a single respondent owning the conventional farm admitted that the health of consumers and family is more important than higher cost of biological crop protection. Continuous reduction in the available pool of pesticides, and consequently reducing the possibility of a legal plant protection, contributed to the abandonment of cultivation of certain plant species, and even more, to farmers' reach the illegal solutions, which is confirmed by the survey results (Kazimierczak et al. 2010; Nowacka et al. 2013). 
According to many authors, about $15 \%$ of plant protection products available on the market are fakes, which often contain contaminants that pose a threat not only to the natural environment, but also to people. Another danger is the fact that in most cases these preparations are registered as self-use products resulting in the exposure of the person, who prepares the working mixture, to the contact with a harmful substance (Hilfert 2012; Ministerstwo Rolnictwa i Rozwoju Wsi 2012). A lack of farmers' awareness against risks of preparing the working mixture for the application, was repeatedly reported (Matyjaszczyk 2007). The conventional farmers, when asked about the most important problem associated with the use of pesticides, mention their high cost and technical problems in application of agrochemicals in the field ( $83 \%$ of respondents). Only $17 \%$ of farmers mentioned the eco-toxicity of pesticides as the largest problem. From the above data, it is clear that farmers do not know about officially imposed limitation or they do, but do not accept the idea of chemicals in agriculture (Agricultural Forum „Awaken”). According to most of them, legal forcing to limit the use of pesticides and their withdrawal from sale is a clear example of hindering the production in every field of agriculture.

Dissatisfied farmers observe the constant changes in the availability of plant protection chemicals related to their legal admission to the sale. According to them, disappearance of nematicides from stores, which help combat parasitic diseases potatoes, is a substantial problem (Agricultural Forum about herbicides). An interesting observation was made based on an analysis of responses from owners of farms operated in an intensive system, who misuse pesticides on their fields, while emphasizing the problem of pesticide toxicity. These farmers declare the will to incur higher costs for the effective biological protection. Therefore, it seems that the problem largely lies not in farmers' malice, but in the absence of any alternatives to chemical protection. What about the fact that owners of large farms are aware of the pesticide dangers, if they have no other possibility of fighting for high yields.

Based on the analysis in the group of farmers familiar with the principles of Integrated Pest Management, it can be concluded that the awareness of dangers associated with the widespread of pesticides within the environment is increasing, even though, according to Pondel (2009), it is not fully satisfactory yet. The level of consciousness is revealed by the farmers' attitude towards the environment, namely their approach to the kind of chemical plant protection used and the actual respect for their withdrawal period (Kazimierczak et al. 2010). The conventional agriculture (intensive production system) is considered the most threatening with the environment degradation, which is conditioned by the use of a large number of pesticide sprays and application of high doses of mineral fertilizers (Olszak 2004). For this reason, emphasis should be put on the training of farmers. Increase in their knowledge upon dangers of chemical plant protection means is a chance to understand the concept of sustainable agriculture. The situation is different referring to the "ecological" awareness of organic farms owners, who cannot use chemicals (Siekierski 2002). Although the idea of sustainable agricultural development was designed to change the attitude of people in relation to respect for natural resources, in practice, it refers to economic-ecological aspects (Kałuża 2009). It should be however noted that each of the farming systems realizes the sustainable development assumptions imposed in varying degrees (Dubas 2007). 
Farmers, who admitted that they had not heard about the obligation to protect the crops according to the integrated system principles, usually did not mention pesticide eco-toxicity as a problem. On the other hand, one must understand the frustrations of farmers, because it limits the pool of available agricultural chemicals, while not giving much in return. In the case of small organic farms, it is relatively easier to control the invasion of pests or weeds using natural methods or biological protection (Dubas 2007). In the case of large-scale farms, the use of bio-pesticides as alternatives to chemical plant protection products, it is impossible (Dubas 2007; Brodzińska 2009; Kałuża 2009; Kazimierczak et al. 2010; Grzesik et al. 2012). The reason can be limited range of available bio-pesticides and high cost of biological control, resulting from the need to purchase bulk quantities. Therefore, owners of conventional farms, who care about protecting the public against the effects of chemicals in agriculture, use not so much the bio-pesticides, while natural methods of plant health supporting (crop rotation, organic and natural fertilization, appropriately selected cultivars of crops).

Many scientists noticed (Kałuża 2009; Nycz-Wróbel 2012) that farmers from different parts of Poland show different interests in Integrated Pest Management system. The main role is played by the state of environmental awareness, which requires constant and intense work. Shaping the pro-ecological attitudes among farmers, but also the whole society, should lead to willingly taking the action for sustainable development of agriculture. Although according to Grzesik et al. (2012), interest in biological methods to improve seed and yield quality has increased in recent years, Nycz-Wróbel (2012) noticed that environmental awareness among people is growing under the influence of their own, positive observations and experiences. The skillful use of instruments of so-called social impact by the state is very important element in creating such awareness among farmers (Kocik 2000; Kiełbasa and Krysztoforski 2009; Hołownicki et al. 2011). Studies carried out by Majewski and Perepeczko (2001) prove the unsatisfactory level of farmers' knowledge of the threat of agricultural chemicals, which was found based on the poll among farmers. Średnicka (2006), who conducted a study of pro-environmental attitudes and ecological awareness among organic and conventional farmers, warns that as many as $49 \%$ of farmers from conventional farms do not have enough knowledge about the negative impact of artificial fertilizers on the environment, while $66 \%$ of this group do not have even a basic knowledge of the risks from the use of pesticides.

Research on the assessment of the environmental awareness of farmers allow to put the thesis that farmers show a huge discrepancy between the views they preach, and their actual behavior. This situation leads to a big difficulty, and consequently, forces to consider many results of this type of research with great caution (Kocik 2000). Comparing the results of different scientists, it should be stated that views and opinions presented by farmers are often contradictory, and their ecological knowledge is usually incomplete and often acquired in a completely random way (Moskal 1995). Pesticides make it much easier for farmers obtaining satisfactory yields. Following the discussions among farmers in online forums, a lack of understanding for the idea of reducing the amount of pesticides into the environment and the withdrawal of plant protection products which have expired or have been disqualified, can be found (Agricultural Forum about herbicides, Agricultural Forum „Awaken”).

Desiccation of cereals using glyphosate is common (Directive 2009/128 / EC of 21 October 2009). In order to facilitate the harvest, uniform ripening of cereals, before the harvest farmers 
apply controversial herbicide spraying (Directive 2009/128 / EC of 21 October 2009). Glyphosate present in grain goes to the subsequent production stages, eventually with feed and bread to the last link of the food chain, which is animal and human (Martini et al. 2012). Many studies alert about contaminated food with series of pesticide residues that interact in a synergistic manner to living organisms. The sum of the toxic effects of individual herbicide components is less than the overall toxic effect, which is caused by a mixture of several herbicide ingredients, and that makes the assessment of their toxicity is a complex process (Rembiałowska et al. 2013). Therefore, a man is exposed to chronic, day by day, receiving chemicals doses (for example, glyphosate in bread), even if small doses, but in the long run destructively operating to an organism (Releya 2005; Richard et al. 2005; Cavas and Konen 2007; Gasnier et al. 2009; Keikothaile et al. 2010; Romano et al. 2010; Martini et al. 2012; Clair et al. 2012; Forma et al. 2013; Shehata et al. 2013). The residues of the pesticide active components were found both on the surface and in the flesh of many agricultural products available on the market. Many scientific reports warn that the highest concentrations of these residues can be found in grapes, apples, and legumes (Bempah et al. 2012; Jardim and Caldas 2012).

This problem is of a global range (Sutton et al. 2010). Washing and thermal treatment of food products typically reduces the amount of pesticides in the semi-finished products, but not always (Keikotlhaile et al. 2010). Further development of a proper behavior and proper attitudes of farmers from an early age is then necessary, because referring to other authors, no-one can expect activities of a pro-ecological character from farmers, who feel that the official solutions restrict them to get profits from the crop, but not knowing the reasons of such situation (Majewski and Perepeczko 2001; Średnicka 2006; Kałuża 2009; Pondel 2009; Kazimierczak et al. 2010; Nycz-Wróbel 2012; Rembiałowska et al. 2013).

\section{CONCLUSIONS}

In most cases, farmers do not know the principles of Integrated Pest Management, or they do, but are not convinced of the validity of their implementation in farms. Many farmers still use pesticides just in case, before the appearance of a real problem of weeds or invading pathogens. The problem is similar to mass prophylactic use of antibiotics and growth hormones during breeding of swine, cattle, and poultry. Profit from crops is the most important for a large group of farmers. They do not know (or do not acknowledge) how dangerous is to spread chemicals throughout the ecosystem for the environment and public health. On the other hand, it is not possible to replace chemical with biological agents (bio-pesticides) in the current large-scale cultivations, because their range is limited and costs of biological protection are much higher than the chemical one (which is related to the application of large quantities of preparations administered several times during the vegetation season). Therefore, the frustrations of farmers, who have limited access to pesticides without increasing the range of other safe biological agents should be understood.

Another case involves desiccation of cereals in order to facilitate the harvest. Such activity should be prohibited, because cost to the public health can be disproportionately high in relation to the short - term profits of a narrow social group. Integrated Pest Management system has a chance of real implementation, if the farmers are convinced of the legitimacy of 
the „ecological” principles introduction in their farms, or if restrictions and official controls resulting in penalties are introduced. However, it is rational and wise to convince the public, to teach from an early age to respect nature, to prove a positive correlation between the use of chemicals in public spaces and an increased prevalence of civilization diseases and reduction of biodiversity.

\section{REFERENCES}

Forum rolnicze „Awaken”, https://forum.wybudzeni.com/index.php?topic=690.0, access: 20.06.2015. [in Polish]

Rolnicze forum o pestycydach Agrofoto.pl, http://www.agrofoto.pl/forum/forum/409-herbicydy/, access: 20.06.2015. [in Polish]

Badowski M. 2004. Skuteczność niszczenia chwastów girostatem przed wschodami ziemniaków [The efficacy of weed control by glyphosate in potato]. Biul. Inst. Hod. Rośl. 233, 265-268. [in Polish]

Bempah C.K., Buah-Kwofie A., Enimil E., Blewu B., AgyeiMartey G. 2012. Residues of organochlorine pesticides in vegetables marketed in Greater Accra Region of Ghana. Food Contr. 25, 537-542.

Brodzińska K. 2009. Kierunki i perspektywy rozwoju program rolnośrodowiskowego w Polsce po 2013 roku [Directions and perspectives of agri - environmental programmes evolution in Poland after the year 2013]. Water Environ. Rural Areas 9, 3(27), 5-18. [in Polish]

Cavas T., Konen S. 2007. Detection of cytogenetic and DNA damage in peripheral erythrocytes of goldfish (Carassius auratus) exposed to a glyphosate formulation. Mutagenesis 22(4), 263-268

Clair E., Mesange R., Travert C., Seralini G., Seralini E. 2012. A glyphosate-based herbicide induces necrosis and apoptosis in mature rat testicular cells in vitro, and testosterone decrease at lower levels. Toxicol. In Vitro 26, 269-279.

Commission Implementing Regulation (EU) 2015/408 of 11 March 2015. On the implementation of Article. 80 paragraph. 7 European Parliament and Council Regulation (EC) No. 1107/2009 concerning the placing of plant protection products and to set a list of potential candidates for substitution, http://eur-lex.europa.eu/legal-content/EN/TXT/?uri=CELEX\%3A32015R0408, access: 20.06.2015.

Cock J. de, Westveer K., Heederik D., Velde E. te, Kooij R. van. 1994. Time to pregnancy and occupational exposure to pesticides in fruit growers in the Netherlands. Occ. Environ. Med. 51, 693-699.

Council Regulation (EC) No. 1257/1999 of 17 May 1999. On support for rural development by the European Agricultural Guidance and Guarantee Fund (EAGGF) and amending and repealing certain regulations. DzU 06.26.1999, L160, as amended. changes, http://eur-lex.europa.eu/legal-content/EN/TXT/?uri=CELEX\%3A31999R1257, access: 20.06.2015.

Directive of the European Parliament and Council Directive 2009/128 / EC of 21 October 2009. Official Journal of the European Union 2009. L 309, 71, http://eur-lex.europa.eu/legal-content/EN/ ALL/?uri=celex\%3A32009L0128, access: 20.06.2015.

Dubas A. 2007. Zrównoważony rozwój w nowoczesnych systemach rolniczych [Sustainable development in modern agricultural systems]. Frag. Agron. 3(95), 71-75. [in Polish]

Forma E., Szymczyk A., Krześlak A. 2013. Wybrane ksenoestrogeny i ich wpływ na zdrowie człowieka [Selected Xenoestrogen and their impact on human health]. Folia Med. Lodzien. 40(1), 79-97. [in Polish]

Gasnier C., Dumont C., Benachour N., Clair E., Changon M. 2009. Glyphosate-based herbicides are toxic and endocrine disruptors in human cell lines. Toxicology 262, 184-191.

Gnusowski B., Nowacka A., Łozowicka B., Szpyrka E. 2011. Badania pozostałości środków chemicznej ochrony roślin w płodach rolnych, roślinnych produktach spożywczych i paszach pochodzących $z$ produkcji ekologicznej $w$ roku 2010 [Pesticide residues in organic food and feed of plant origin]. J. Res. App. Agr. Eng. 56(3), 102-107. [in Polish] 
Grzesik M., Janas R., Górnik K., Romanowska-Duda Z. 2012. Biologiczne i fizyczne metody stosowane w produkcji i uszlachetnianiu nasion [Biological and physical methods of seed production and processing]. J. Res. App. Agr. Eng. 57(3), 147-152. [in Polish]

Hayes T., Tsui M., Hoang A., Haeffele C., Vonk A. 2003. Atrazine - induced hermaphroditism at $0.1 \mathrm{ppb}$ in American leopard frogs (Rana pipiens): Laboratory and field evidence. Environ. Health Persp. 111(4), 568-575.

Hayes T.B., Anderson L.L., Beasley V.R., De Solla S.R., Iguchi T., Ingraham H., Kestemont P., Kniewald J., Kniewald Z., Langlois V.S., Luque E.H., McCoy K.A., Muñoz - de - Toro M., Oka T., Oliveira C.A., Orton F., Ruby S., Suzawa M., Tavera-Mendoza L.E., Trudeau V.L., Victor-Costa A.B., Willingham E. 2011. Demasculinization and feminization of male gonads by atrazine: Consistent effect across vertebrate classes (review). J. Steroid Biochem. 127(1-2), 64-73.

Hilfert G. 2012. Ministry of Economy, Transport and Innovation, Plant Health Inspection Service, Germany: Detection of shipments containing illegal PPPs in the Port of Hamburg - Anti Counterfeit processes and activities. CEUREG Forum, AGES Conference Centre, Vienna, Austria,15-16.10.2012 [typescript].

Hołownicki R., Doruchowski G., Godyń A., Świechowski W. 2011. Inżynieria ochrony roślin w dyrektywach UE [Engineering plant protection in EU directives]. Inż. Rol. 4(129), 75-84. [in Polish]

Jardim A.N.O., Caldas E.D. 2012. Brazilian monitoring programs for pesticide residues in food - results from 2001 to 2010. Food Control 25, 607-616.

Kałuża H. 2009. Świadomość ekologiczna rolników a zrównoważony rozwój rolnictwa [Ecological awareness of farmers and the sustainable development of agriculture]. J. Agr. Rural Develop. 3(13), 63-71. [in Polish]

Kazimierczak R., Skąpska W., Rembiałowska E. 2010. Ocena świadomości ekologicznej i postaw proekologicznych wśród rolników ekologicznych i konwencjonalnych w powiecie grawiejskim [Evaluation of environmental awareness and pro-environmental attitudes among the organic farmers and conventional in the grawiejski's district]. J. Res. Appl. Aci. Eng. 55(3), 171-178. [in Polish]

Keikotlhaile B.M., Spanoghe P., Steurbaut W. 2010. Effects of food processing on pesticide residues in fruits and vegetables: A meta-analysis approach. Food Chem. Toxicol. 48, 1-6.

Kiełbasa B., Krysztoforski M. 2009. Potrzeba rolników w doradztwie w opinii Wojewódzkich Ośrodków Doradztwa Rolniczego [Farmers' neediness of consulting in the opinion of the Provincial Agricultural Advisory Centres]. Zag. Dor. Rol. 2, 43-53. [in Polish]

Kocik L. 2000. Między przyrodą, zagrodą i społeczeństwem: społeczno-kulturowe problemy ekologii wsi i rolnictwa. Wyd. I, Kraków, Wydaw. UJ. [in Polish]

Kowalska J., Golka W., Ptaszyński S. 2012. Uwarunkowania legislacyjne dotyczące środków wspomagających uprawę roślin i wymagania techniczne ich aplikacji [Legislation aspects of using the strengtheners in plant cultivation and technical requirements for their application]. PIR (IV-VI), 2(76), 47-54. [in Polish]

Kucharski M., Sadowski J., Kieloch R. 2012. Adiuwanty w zabiegach przedwschodowych - wpływ na skuteczność diflufenikanu i jakość ziarna pszenicy ozimej [Adjuvants in preemergence application influence on diflufenican efficacy and quality of winter wheat grain. Progr. PI. Prot. / Post. Ochr. Rośl. 52(1), 51-54. [in Polish]

Lisek J. 2010. Skuteczność chwastobójcza mieszaniny glifosatu i pyraflufenu stosowanej w sadach jabłoniowych [Response of weeds to mixture of glyphosate and pyraflufen applied in apple orchards]. Prog. Plant Prot. 50(2), 811-814. [in Polish]

Majewski E., Perepeczko B. 2001. Skuteczność chwastobójcza mieszaniny glifosatu i pyraflufenu stosowanej w sadach jabłoniowych. Red. E. Majewski. Warszawa, Wydaw. SGGW, 164. [in Polish]

Martini C.N., Gabrielli M., Vila M.C. del. 2012. A commercial formulation of glyphosate inhibits proliferation and differentiation to adipocytes and induces apoptosis in 3T3-L1 fibroblasts. Toxicol. In Vitro 1007-1013.

Matyjaszczyk E. 2007. Wpływ przyjęcia wybranych unijnych wymagań mających na celu zapewnienie bezpieczeństwa żywności i środowiska na rynek środków ochrony roślin w Polsce [The influence of implementation of selected EU requirements ensuring food and environmental safety on the Polish market of plant protection products]. Probl. Rol. Świat 2(17), 2, 406-414. [in Polish] 
Ministerstwo Rolnictwa i Rozwoju Wsi. 2012. Komunikat prasowy w sprawie stosowania środków ochrony roślin łącznie i w dawkach obniżonych z dnia 27.09.2012, http://www.minrol.gov.pl/pol/ /Ministerstwo/BiuroPrasowe/Informacje-Prasowe/Stosowanie-srodkow-ochronyroslin, access: 20.06.2015. [in Polish]

Morais M.R. de, Zanardi O.Z., Rugno G.R. 2016. Impact of five insecticides used to control citrus pests on the parasitoid Ageniaspis citricola Longvinovskaya (Hymenoptera: Encyrtidae). Ecotoxicol. 25, 1011-1020.

Moskal S. 1995. Świadomość ekologiczna mieszkańców wsi [Ecological awareness of the inhabitants of the village]. Wieś Rol. 4, 20. [in Polish]

Nowacka A., Gnusowski B., Walorczyk S., Walorczyk S., Drożdżyński D., Raczkowski M., Hołodyńska A., Frąckowiak D., Wójcik A., Ziółkowski A., Przewoźniak M., Swoboda W., Rzeszutko U., Domańska I., Jurys J., Łozowicka B., Kaczyński P., Rutkowska E., Jankowska M., Hrynko I., Szpyrka E., upar J., Rogozińska K., Kurdziel A., Słowik-Borowiec M., Szala J., Szponik M., Michel M. 2013. Kontrola pozostałości środków ochrony roślin w płodach rolnych w 2012 roku. Streszczenia 53. Sesji Naukowej Instytutu Ochrony Roślin - PIB, Poznań 7-8.02.2013, [b.w.], 72. [in Polish]

Nycz-Wróbel J. 2012. Environmental awareness of society and the resulting environmental hazards (for example, residents' opinions Podkarpackie Province). Zesz. Nauk. Politech. Rzesz. 286, 19(3), 63-76.

Official Gazette of the Minister of Agriculture and Rural Development, http://isap.sejm.gov.pl/ /DetailsServlet?id=WDU20130000455, access: 20.06.2016. [in Polish]

Olszak R.W. 2004. Środek chemiczny w integrowanej ochronie roślin. w: Materiały Ogólnopolskiej Konferencji, Skierniewice 27.10.2004. Skierniewice, ISiK, 25-232. [in Polish]

Pondel H. 2009. Wielkopolscy rolnicy i proekologiczny rozwój gospodarstw [Wielkopolska voivodship's farmers and pro-environmental development of the farms]. Acta Sci. Pol., Oeconomia 8(2), 111-120. [in Polish]

Relyea R.A. 2005. The lethal impact of Roundup on aquatic and terrestrial amphibians. Ecol. Appl. 15, 1118-1124.

Rembiałowska E., Ciesielska R., Owczarek E, Hallmann E. 2013. Ocena świadomości ekologicznej oraz postaw prośrodowiskowych wśród rolników ekologicznych i konwencjonalnch z województwa mazowieckiego [Evaluation of environmental awareness and pro-environmental attitudes among the organic farmers and conventional from Mazovia Voivodeship]. J. Res. Appl. Aric. Eng. 58(4), 135-140. [in Polish]

Richard S., Moslemi S., Sipahutar H., Benachour N., Seralini G. 2005. Differential effects of glyphosate and Roundup on human placental cells and aromatase. Environ. Health Persp. 113(6), 716-720.

Romano R.M., Romano M.A., Bernardi M.M., Furtado P.V., Oliveira C.A. 2010. Prepubertal exposure to commercial formulation of the herbicide glyphosate alerts testosterone levels and testicular morphology. Arch. Toxicol. 84, 309-317.

Shehata A.A., SchrodI W., Aldin A.A., Hafez M., Kruger M. 2013. The effect of glyphosate on potential pathogens and beneficial members of poultry microbiota in vitro. Curr Microbiol. 66, 350-358.

Siekierski J. 2002. Rolnictwo i obszary wiejskie Polska wobec współczesnych wyzwań związanych z rozwojem i integracją. Tarnów, Małopolsk. Wyż. Szk. Ekonom. w 147-154. [in Polish]

Sikorska K., Wędzisz A. 2009. Nowoczesne pestycydy - Spinosad [Modern pesticides - Spinosad]. Bromat. Chem. Toksykol. 62(2), 203-212. [in Polish]

Sopińska A., Grochała A., Niezgoda J. 2000. Wpływ wody zanieczyszczonej herbicydem Roundup na organizm ryb [Influence of water polluted with herbicide Roundup on the organism of fish]. Med. Weter. 56, 593-597. [in Polish]

Średnicka D. 2006. Ocena świadomości ekologicznej i postaw ekologicznych wśród rolników ekologicznych i konwencjonalnych z województwa mazowieckiego. Praca dyplomowa. Warszawa, SGGW (typescript). [in Polish] 
Sutton P., Perron J., Giudice, L.C., Woodruff T.J. 2010. Pesticides matter. A primer for reproductive health physicians. Program on Reproductive Health and the Environment. San Francisco, University of California, http://prhe.ucsf.edu/prhe/pdfs/pesticidesmatter_whitepaper.pdf, access: 20.06.2015.

Wasim A., Dwaipayan S., Ashim Ch. 2009. Impact of pesticides use in agriculture: their benefits and hazards Interdiscip. Toxicol. 2(1), 1-12.

Abstract. The study was aimed at assessing the progress of integrated pest management (IPM) implementation into agricultural practices. Assessment of farmers' attitude to the new EU policy to reduce the use of insecticides as well as evaluating the real possibilities of biological methods use for plant protection was analyzed. Almost $60 \%$ of farmers whose farms were conducted in a conventional system declared the use of pesticides prophylactically. Farmers conducted intensive agriculture do not know the principles of IPM (prohibition of pesticides abuse). However, it is possible that these farmers know the restrictions introduced in 2014 without accepting them. It has been observed that in the group of farmers declaring the knowledge upon principles of IPM, the proportion of respondents aware of pesticides ecotoxicity increases. Therefore, a continuous education of farmers seems justified, but at simultaneous expanding the range of biological products and support mechanisms for farmers, who quit the intensive use of chemicals. 